\title{
Asymptomatic coronavirus disease followed by symptomatic reinfection in a patient with monoclonal gammopathy of undetermined significance: A case report
}

\author{
Varsha Narayanan \\ From Consultant, Department of Family Medicine and Holistic Health, Dr. Varsha's Health Solutions, Andheri West, Mumbai, Maharashtra, India
}

\begin{abstract}
Coronavirus disease (COVID-19) pandemic has been present for over a year and has been seen to behave unpredictably in different people especially those with other underlying health conditions. Monoclonal Gammopathy of Undetermined Significance (MGUS) is a rare condition that can alter immune responses. There are few case reports of COVID in people with MGUS and most of these are in elderly people often with associated comorbidities. The mutual impact of COVID and MGUS in younger people ( $<50$ years) has been far less explored, and therefore, this case report would add to such data. Although there is no conclusive evidence to suggest that MGUS increases predisposition or significantly impacts the clinical course and outcomes of COVID-19, it can have some bearing on serological assessment in both COVID infected or vaccinated individuals.
\end{abstract}

Key words: Antibodies, Asymptomatic, Coronavirus disease, Monoclonal Gammopathy of undetermined significance, Real-time reverse transcriptase polymerase chain reaction

$\mathrm{C}$ oronavirus disease (COVID-19) has been present and spreading globally for more than a year and has affected over 100 million people across more than 100 countries with over 2 million deaths (average mortality rate of $2-3 \%$ ) [1]. It is a flu-like illness seen to cause more severity, hospitalization, complications, and mortality in the elderly and people with comorbidities. COVID has been showing the second wave in many countries including India, where the second wave is being seen from March 2021. Monoclonal Gammopathy of Undetermined Significance (MGUS) is considered a plasma cell dyscrasia with the presence of the $\mathrm{M}$ protein (myeloma protein or monoclonal immunoglobulin), an abnormal antibody usually discovered during laboratory tests [2].

The level of this antibody is lower $(\leq 3 \mathrm{~g} / \mathrm{dl})$ in MGUS with no end-organ damage, as compared to multiple myeloma, and it rarely presents any symptoms or health problems. Population prevalence of MGUS is around 2-3\% in those aged 50 years or more but $<1 \%$ below 50 years, and $\leq 0.3 \%$ below 40 years of age [3]. However, since MGUS can lead to multiple myeloma in about $1 \%$ a year, annual follow-up, and health check-up is recommended, with close monitoring of high-risk cases [4]. There is still very little evidence or medical insight available on the mutual effects of COVID in people with MGUS.

\section{Access this article online}

Received - 01 April 2021

Initial Review - 16 April 2021

Accepted - 24 April 2021

DOI: $10.32677 / I J C R .2021 . v 07.105 .002$

\section{CASE REPORT}

A 45-year-old female corporate executive was diagnosed with MGUS during a routine detailed pre-employment medical check-up. Serum protein electrophoresis showed M band in gamma region quantitated at $6.2 \%(0.42 \mathrm{~g} / \mathrm{dl})$ (Fig. 1a); however, further markers evaluated for high-risk MGUS were in the normal range or negative (Fig. 1b). The rest of all the blood tests were normal. The patient was already diagnosed with Grade 1 hypertension 3 years back and controlled on telmisartan $40 \mathrm{mg}$ once daily. She was advised yearly health check-ups and follow-up.

Three months later, the patient underwent nasal swab realtime reverse transcriptase polymerase chain reaction (RT-PCR) for COVID as a routine pre-travel procedure and requirement for flying. While her first RT-PCR was negative on initiating travel, the second done on her return from a 10-day official tour of 2-3 cities, was positive with a cycle threshold $(\mathrm{Ct})$ of 32 , suggesting low viral load and transmissibility [5]. She had no symptoms of COVID or any other infections or illness. She was kept under isolation and observation with 4 hourly temperature and pulse oximetry monitoring, and further evaluated with blood tests (Table 1).

She was started on multi-vitamin supplements including B complex, C, and D, with zinc. COVID RT-PCR was repeated on the $5^{\text {th }}$ day and was found to be negative. The patient remained

Correspondence to: Varsha Narayanan, 1305 Montreal, Shastri Nagar, Andheri West, Mumbai - 400 053, Maharashtra, India. E-mail: info@drvarsha.com

(C) 2021 Creative Commons Attribution-NonCommercial 4.0 International License (CC BY-NC-ND 4.0). 


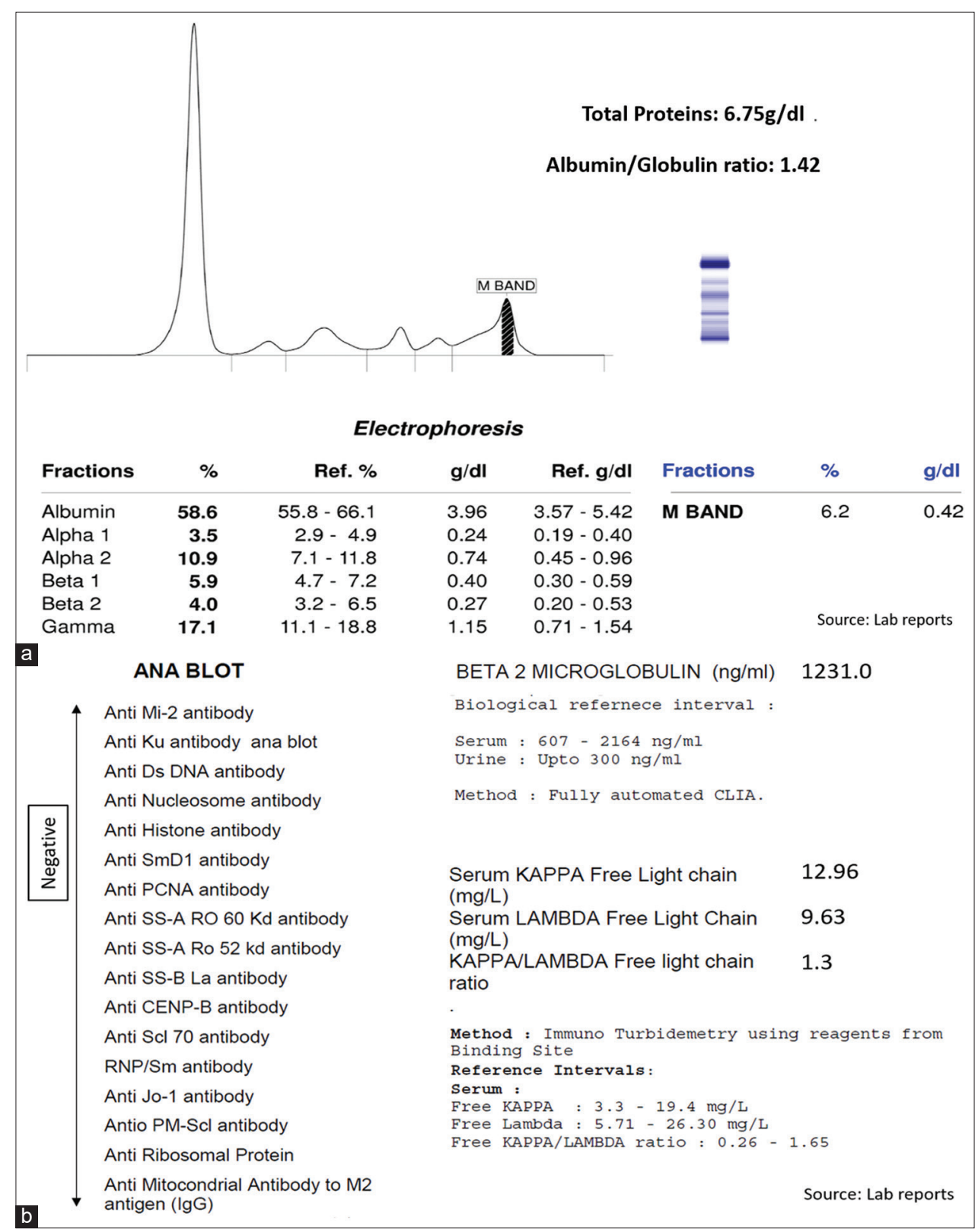

Figure 1: Diagnostic tests for Monoclonal Gammopathy of Unknown Significance. (a) Serum protein electrophoresis; (b) Other markers

asymptomatic, with normal temperature and oxygen saturation (maintained above 95\%) through the 5 days of observation. At the end of 2 weeks, the patient had remained without any symptoms and felt perfectly well. Anti-severe acute respiratory syndrome coronavirus 2 (SARS-CoV-2) total antibodies (by serum ECLIA) were estimated, which was non-reactive at 0.0668 (laboratory cutoff for reactive $\geq 1$ ).

Forty days later after testing negative with RT-PCR, she developed fever $\left(101^{\circ} \mathrm{F}\right)$, sore throat, and dry cough. She was immediately asked to isolate herself and RT-PCR was performed which was positive with a cycle threshold $(\mathrm{Ct})$ of 18 , suggesting high viral load and transmissibility [5]. She was kept under isolation and observation with 4 hourly temperature and pulse oximetry monitoring, and further evaluated with blood tests (Table 1). She was given favipiravir, paracetamol, and symptomatic treatment for cough along with continuing the multi-vitamin and zinc supplements. Fever was absent by the $3^{\text {rd }}$ day, and full recovery of symptoms seen with oxygen saturation maintained above 95\%. Antiviral treatment was given for 10 days, and the 14-day isolation period was completed.

She was advised to follow all the protocols for COVID and vaccine administration after 8 weeks as well as an annual health check-up for MGUS. Anti- SARS-CoV-2 total antibodies (by serum ECLIA) were estimated, which was reactive at 2.06 (laboratory cutoff for reactive $\geq 1$ ).

\section{DISCUSSION}

MGUS is usually an incidental diagnosis, as in this case. Although the rate of progression to myeloma is only $1 \%$ per year, this rate does not decrease with time; therefore, lifelong regular follow-up is recommended. Markers of high-risk MGUS in terms of progression to multiple myeloma such as $\mathrm{M}$ protein of at least 1.5 $\mathrm{g} / \mathrm{dl}$, monoclonal immunoglobulin other than IgG, and an abnormal 
Table 1: Real-time reverse transcriptase polymerase chain reaction and blood tests reports comparison

\begin{tabular}{lcc}
\hline Test & $\begin{array}{c}\text { Asymptomatic } \\
\text { first infection }\end{array}$ & $\begin{array}{c}\text { Symptomatic } \\
\text { reinfection }\end{array}$ \\
\hline $\begin{array}{l}\text { Real-time reverse transcriptase } \\
\text { polymerase chain reaction cycle }\end{array}$ & 32 & 18.8 \\
threshold & & \\
Hemoglobin & $11.8 \mathrm{~g} / \mathrm{dl}$ & $12.2 \mathrm{~g} / \mathrm{dl}$ \\
Red cell distribution width & $13.3 \%$ & $13.3 \%$ \\
Neutrophil/lymphocyte ratio & 1 & 1.8 \\
C reactive protein & $2 \mathrm{mg} / \mathrm{L}$ & $4 \mathrm{mg} / \mathrm{L}$ \\
D dimer & $300 \mathrm{ng} / \mathrm{ml}$ & $225 \mathrm{ng} / \mathrm{ml}$ \\
Ferritin & $7.1 \mathrm{ng} / \mathrm{ml}$ & $10.7 \mathrm{ng} / \mathrm{ml}$ \\
Lactate dehydrogenase & $142 \mathrm{U} / 1$ & $156 \mathrm{U} / 11$ \\
Interleukin 6 & $2.2 \mathrm{pg} / \mathrm{ml}$ & $9.3 \mathrm{pg} / \mathrm{ml}$ \\
Anti-severe acute respiratory & Non-reactive & Reactive \\
syndrome coronavirus 2 total & & \\
antibodies (after 2 weeks) & & \\
\hline
\end{tabular}

serum free light-chain ratio (kappa:lambda light chains) were absent in this case. There is some evidence to suggest that since MGUS may be associated with hypogammaglobulinemia (in almost 25\%) and sub-optimal immunity, hypercoagulability, and a greater propensity for end-organ damage, this could possibly increase the susceptibility, severity, and mortality (up to 15\%) of COVID-19 in the elderly population who are already in a higher COVID risk group due to age and associated comorbidities [6]. However, there is a lack of evidence to suggest the same in younger populations below 50 years. Whether MGUS actually significantly impacts the clinical course of COVID needs study in a larger population, and as of now, there is no such data to suggest that MGUS may impart either additional risks, or affect patient outcomes in COVID [7].

In this case, the patient was initially asymptomatic, showed a negative RT-PCR test within 5 days and no antibody response at 2 weeks, followed by developing symptoms and testing positive around 6 weeks later. The patient raised the question whether the first RT-PCR test when asymptomatic was a false-positive result. Factors such as sample contamination, technological variations in a number of contiguous nucleic acid bases, second separation technique, amplification errors with short probes, and datasoftware errors can yield a false positive [8]. Such false positives have seen to be rare at the rate of $0.8-4 \%$. It is to be noted that in this case, the first positive RT-PCR was from a standardized accredited laboratory, displaying the cycle threshold, while the patient had significant exposure to COVID due to travel, visiting multiple venues, and mingling with several people, therefore a false positive RT-PCR seemed unlikely.

The reason to explain achieving early RT-PCR negative status after the initial infection could be that asymptomatic persons with low viral load show early viral clearance $[9,10]$. A study showed a median viral clearance time of 7 days in asymptomatic versus 16.5 days in mild-moderate symptomatic patients [11]. The virusspecific antibody response in asymptomatic COVID positive people has been seen to be significantly lower than the symptomatic group. A study showed more than $80 \%$ of asymptomatic individuals had a reduction in neutralizing antibody levels, during the early convalescent phase with $40 \%$ (vs. $13 \%$ in the symptomatic group) becoming seronegative for IgG in the early convalescent phase, suggesting that asymptomatic individuals had a weaker immune response to SARS-CoV-2 infection [12]. The reduction in IgG and neutralizing antibody levels in the early convalescent phase might have implications for immunization strategy and serological surveys, as well as for the risk of early re-infection, as seen in this case [13]. It is also to be noted that the re-infection occurred during an aggressive resurge of COVID in India and also the identification of double mutant more infective variants [14].

MGUS is known to be a condition that can decrease antibody response to infections and vaccination [6,15]. People with MGUS may have impaired anti-viral antibody response and a lower SARS-CoV-2 specific IgG as compared to the general population [6]. However, the clinical and real-world significance and impact of this on COVID susceptibility, clinical course, and immunological response are still not ascertained, and the same would be more significant in the elderly with waning immunity. All infected people especially with initial low viral load should be made aware of possible re-infection anytime and therefore always follow standard precautions. As per recommendations, all people with MGUS should be vaccinated against COVID-19; however, more research on post-vaccination seroconversion and SARS$\mathrm{CoV}-2$-specific IgG titer antibody titers is required in this group, along with the effect of age and other comorbidities.

\section{CONCLUSION}

Asymptomatic people testing positive with RT-PCR for COVID can show low viral load and transmissibility, along with early viral clearance, followed by re-infection within a short time span. The presence of MGUS in younger people $<50$ years may not affect the clinical course or outcomes in COVID. However, a person with MGUS with asymptomatic or mild COVID may show the absence of COVID-specific antibodies and immunological response on serological testing. These points can be kept in mind during patient counseling, serological surveys, and population vaccination drives. Research and studies in a larger number of people with MGUS, especially younger patients with high-risk MGUS, are required to add further medical insights on how this condition impacts risk, course, and outcomes in COVID, along with a response to vaccination.

\section{REFERENCES}

1. COVID-19. World Health Organization Coronavirus (COVID-19) Dashboard; 2021. Available from: https://wwwcovid19.who.int. [Last accessed on 2021 Mar 23].

2. Pang L, Rajkumar SV, Kapoor P, Buadi F, Dispenzieri A, Gertz M, et al. Prognosis of young patients with monoclonal gammopathy of undetermined significance (MGUS). Blood Cancer J 2021;11:26.

3. Gupta R, Dahiya M, Kumar L, Shekhar V, Sharma A, Ramakrishnan L, et al. Prevalence of monoclonal gammopathy of undetermined significance in India-a hospital-based study. Clin Lymphoma Myeloma Leuk 2018;18:e345-50.

4. Ravindran A, Lackore KA, Glasgow AE, Drake MT, Hobbs MA, Kourelis T, 
et al. Monoclonal gammopathy of undetermined significance: Indications for pre-diagnostic testing, subsequent diagnoses, and follow-up practice at Mayo Clinic. Mayo Clin Proc 2020;95:944-54.

5. Sarkar B, Sinha RN, Sarkar K. Initial viral load of a COVID-19-infected case indicated by its cycle threshold value of polymerase chain reaction could be used as a predictor of its transmissibility-an experience from Gujarat, India. Indian J Community Med 2020;45:278-82.

6. Jain A, Ramasamy K. Potential 'significance' of monoclonal gammopathy of 'undetermined significance' during COVID-19 pandemic. Blood Cells Mol Dis 2020;85:102481.

7. Gonzalez-Lugo JD, Bachier-Rodriguez L, Goldfinger M, Shastri A, Sica RA, Gritsman K, et al. A case series of monoclonal gammopathy of undetermined significance and COVID-19. Br J Haematol 2020;190:e130-3.

8. Roy S. Physicians' dilemma of false-positive RT-PCR for COVID-19: A case report. SN Compr Clin Med 2021;Jan 2:1-4.

9. Xiao T, Wang Y, Yuan J, Ye H, Wei L, Liao X, et al. Early viral clearance and antibody kinetics of COVID-19 among asymptomatic carriers. Front Med 2021;8:595773

10. Uhm JS, Ahn JY, Hyun JH, Sohn Y, Kim JH, Jeong SJ, et al. Patterns of viral clearance in the natural course of asymptomatic Coronavirus disease 2019 (COVID-19): Comparison with symptomatic non-severe COVID-19. Int J Infect Dis 2020;99:279-85.

11. Samrah SM, Al-Mistarehi AH, Kewan T, Al-Khatib SM, Ibnian AM, Samrah RS, et al. Viral clearance course of COVID-19 Outbreaks. J Multidiscip Healthc 2021;14:555-65.

12. Long, QX, Tang, XJ, Shi, QL, LiQ, Deng HJ, Yuan J, et al. Clinical and immunological assessment of asymptomatic SARS-CoV-2 infections. Nat Med 2020;26:1200-4.

13. Sharma R, Sardar S, Arshad AM, Ata F, Zara S, Munir W. A patient with asymptomatic SARS-CoV-2 infection who presented 86 days later with COVID-19 pneumonia possibly due to reinfection with SARS-CoV-2. Am J Case Rep 2020;21:e927154.

14. Press Information Bureau. Ministry of Health and Family Welfare-Genome Sequencing by INSACOG Shows Variants of Concern and a Novel Variant in India; 2021. Available from: https://www.pib.gov.in/pressreleaseiframepage. aspx?prid=1707177\#: : text=genome $\% 20$ sequencing $\% 20$ by $\% 20$ insacog\%20 shows,a $\% 20$ nove $1 \% 20$ variant $\% 20$ in $\% 20$ india\&text $=$ the $\% 20$ indian $\% 20$ sars $\% 2 \mathrm{dcov} \% 2 \mathrm{~d} 2$, on $\% 2025 \% 2 \mathrm{f} 12 \% 2 \mathrm{f} 2020$. [Last accessed on 2021 Apr 10].

15. Dhodapkar MV, Dhodapkar KM, Ahmed R. Viral immunity and vaccines in hematologic malignancies: Implications for COVID-19. Blood Cancer Discov 2021;2:1-4.

Funding: None; Conflicts of Interest: None Stated.

How to cite this article: Narayanan V. Asymptomatic coronavirus disease followed by symptomatic reinfection in a patient with monoclonal gammopathy of undetermined significance: A case report. Indian J Case Reports. 2021;7(5):178-181. 